\title{
Impact of ameliorants on the biological condition of oil-contaminated black soil
}

\author{
Minnikova Tatiana Vladimirovna*, Kolesnikov Sergey Il'ch and Kazeev Kamil' Shagidullovich \\ Southern Federal University, Academy of Biology and Biotechnology by Ivanovsky, \\ Rostov, Russian Federation.
}

[Received: June 24, 2019 Accepted: August 27, 2019]

\begin{abstract}
The impact of ameliorants on the biological condition of ordinary black soil in the south of European Russia (Rostov district) after oil pollution has been analyzed. The impact of ameliorants of different nature like urea, glauconite, potassium humate and Dop-Uni (bacterial preparation) on the biological condition of oil-contaminated ordinary black soil has been analyzed. According to the stimulating effect on the biological activity of oilcontaminated black soil, ameliorants were ranked in the following order: potassium humate > Dop-Uni > urea. According to the efficiency in stimulating oil breakdown, the ameliorants studied form the following sequence: potassium humate $>$ Dop-Uni $>$ urea. The above rank did not include glauconite since its mode of action is based not on the stimulation of oil breakdown, but on its fixation. In case of combined application of urea and potassium humate, there was a synergistic effect indicating the reasonability of their combined application. When applying urea and Dop-Uni, there was an antagonistic effect. According to the sensitivity to ameliorants in oil-contaminated black soils, biological parameters form the following sequence: content of labile organic matter $\geq$ invertase activity $>$ catalase activity $>$ phosphatase activity $>$ root length $\geq$ shoot length. According to information value, the used biological parameters of soil condition form the following sequence: invertase activity $>$ content of labile organic matter $\geq$ catalase activity $>$ root length $>$ shoot length $>$ phosphatase activity.
\end{abstract}

Keywords: Black soil, oil pollution, biological diagnostics, urea, glauconite, potassium humate, Dop-Uni (bacterial preparation)

\section{Introduction}

Millions of hectares of soil are contaminated by oil and oil products worldwide every year. Many researchers have found that oil pollution leads to the degradation of biological condition of soils and, as a consequence, disruption of their agricultural and ecological functions (Ismailov and Khaziev et al., 1988; Gabbasova et al., 1997; Kireeva et al., 1998; Trofimov et al., 2000; Pikovskyi et al., 2003; Kolesnikov et al., 2006, 2011, 2012, 2013; Erkenova et al., 2016; Minnikova et al., 2017, 2018a, 2018b; Polyak et al., 2018). Currently, various amelioration methods were used for the elimination of soil pollution by oil and oil products. Various compounds were used as ameliorants, which were different in their nature and mode of action. They included bacterial preparations, fertilizers and mineral adsorbents (Kanis'kin et al., 2007; Kolesnikov et al., 2011; Filatov et al., 2011; Dindar et al., 2013; Ahmad et al., 2015; Efremova et al., 2016; Ashraf et al., 2017; Batool et al., 2017; Minnikova et al., 2018a, b, c). In this case, the major focus was on the efficiency of oil breakdown and the change in soil condition remains under studied. Biological parameters were the most meaningful indicators for the assessment of soil condition in case of oil pollution, as well as in case of other anthropogenic effects, which are the first to react to the external influence on soil and correlate to the pollutant concentration in soil (Khaziev et al., 1988: et al., 2006, 2007, 2011; Kireeva et al., 2009; Kazeev et al., 2016; Abdul Latif et al., 2019; Suleymanov et al., 2019).

The impact of ameliorants of different nature (source of nitrogen - urea, mineral adsorbent - glauconite, humic agent - potassium humate, bacterial preparation - Dop-Uni) and with different mode of action (oil breakdown or fixation) on the biological condition of black soil was assessed for the first time. The combined and separate application of ameliorants, dynamics of rehabilitation of soil biological condition and various degrees of oil pollution were studied. The assessment was made on of the basis of sensitivity and information value of black soil biological parameters after the application of ameliorants.

The objective of the work was to study the impact of ameliorants of various nature (urea, glauconite, potassium

\footnotetext{
*Email: loko261008@yandex.ru
} 
humate and Dop-Uni) on the biological condition of oilcontaminated ordinary black soil.

\section{Materials and Methods}

The study object is carbonaceous ordinary black soil. Black soils cover about 153 million ha or 1.53 million square $\mathrm{km}$ of total soil mantle in Russia representing about $52 \%$ of land resources in the world. Place of sampling is the south of European Russia. Soil was sampled from the arable layer $(0-25 \mathrm{~cm})$ in the Botanic Garden of the Southern Federal University (Rostov Oblast, Rostov-on-Don). Biological and physicochemical properties of ordinary black soils were considered in detail. Content of organic matter is g 24 hour $^{-1}$, phosphatase activity is $2.8 \mathrm{mg}$ of $\mathrm{P}_{2} \mathrm{O}_{5} 100 \mathrm{~g}$ hour ${ }^{-1}$.

The impact of four ameliorants of different nature (source of nitrogen-urea, mineral adsorbent-glauconite, humic agent-potassium humate, bacterial preparation Dop-Uni) on the biological properties of ordinary black soil at various levels of oil pollution (5 and $10 \%$ of soil weight) at different times from the date of pollution (30,60 and 90 days) was studied.

For the purpose of modelling black soil pollution by oil, the oil with density of $0.818 \mathrm{~g} \mathrm{~m}^{-3}, 0.43 \%$ weight parts of sulfur, $0.0028 \%$ of admixtures, and $0.03 \%$ of water at

Model experiment No. 1. Oil pollution $-5 \%$ of soil weight. Applied ameliorants: urea, potassium humate, glauconite, Dop-Uni. Exposure time: 30 days.

Experiment design:

$\begin{array}{ll}\text { 1. } & \text { Control }(\mathrm{C})-\text { uncontaminated ordinary } \\ \text { black soil } \\ \text { 2. } & \mathrm{C}+\text { glauconite } \\ \text { 3. } & \mathrm{C}+\text { Dop-Uni } \\ \text { 4. } & \mathrm{C}+\text { urea } \\ \text { 5. } & \mathrm{C}+\text { potassium humate } \\ \text { 6. } & \mathrm{C}+\text { glauconite }+ \text { Dop-Uni } \\ \text { 7. } & \mathrm{C}+\text { glauconite }+ \text { urea } \\ \text { 8. } & \mathrm{C}+\text { glauconite }+ \text { potassium humate } \\ \text { 9. } & \mathrm{C}+\text { Dop-Uni }+ \text { urea } \\ \text { 10. } & \mathrm{C}+\text { Dop-Uni }+ \text { potassium humate } \\ \text { 11. } & \mathrm{C}+\text { urea }+ \text { potassium humate } \\ \text { 12. } & \mathrm{C}+\text { Dop-Uni }+ \text { potassium humate }+ \text { urea } \\ \text { 13. } & \mathrm{C}+\text { urea }+ \text { potassium humate }+ \\ & \text { glauconite } \\ \text { 14. } & \mathrm{C}+\text { Dop-Uni }+ \text { potassium humate }+ \text { urea }\end{array}$
+ glauconite
15. Ordinary black soil contaminated by oil, $5 \%$ of soil weight $(\mathrm{O})$

16. $\mathrm{O}+$ Glauconite

17. O + Dop-Uni

18. $\mathrm{O}+$ urea

19. $\mathrm{O}+$ potassium humate

20. O + glauconite + Dop-Uni

21. O + urea

22. $\mathrm{O}+$ glauconite + potassium humate

23. O + Dop-Uni + urea

24. $\mathrm{O}+$ Dop-Uni + potassium humate

25. $\mathrm{O}+$ urea + potassium humate

26. $\mathrm{O}+$ Dop-Uni + potassium humate + urea

27. $\mathrm{O}+$ urea + potassium humate + glauconite

28. $\quad \mathrm{O}+$ Dop-Uni + potassium humate + urea + glauconite

Table 1: Characteristics of ameliorants and requirements for their application, in $\mathrm{gram}_{\mathrm{kg}}^{-1}$ soil

\begin{tabular}{|c|c|c|c|}
\hline Compound & Characteristic & Mode of action & Normal value \\
\hline Glauconite & Gray-brown fine powder & $\begin{array}{l}\text { Natural mineral loamy adsorbent. Oil adsorption, at } \\
\text { glauconite: oil ratio of } 1: 6\end{array}$ & 8.3 \\
\hline Dop-Uni & $\begin{array}{l}\text { Peat powder with bacterial } \\
\text { strains }\end{array}$ & $\begin{array}{l}\text { Source of bacterial strains of oil degrading bacteria. It } \\
\text { comprises } 3 \text { strains of oil degrading bacteria. }\end{array}$ & 25.0 \\
\hline $\begin{array}{l}\text { Potassium } \\
\text { humate }\end{array}$ & Dark brown solution & $\begin{array}{l}\text { Source of humic compounds. Stimulation of native oil } \\
\text { degrading biota }\end{array}$ & 5.0 \\
\hline Urea & Large white dense granules & $\begin{array}{l}\text { Source of mineral nitrogen. Adjustment of } \mathrm{C}: \mathrm{N} \text { ratio up to } \\
5: 1\end{array}$ & 18.3 \\
\hline
\end{tabular}

$1.3 \%$, labile organic matter-29.6 mg kg-1 soil, catalase activity is $7.3 \mathrm{~mL}$ of $\mathrm{O}_{2} \mathrm{~g} 1 \mathrm{~min}^{-1}$, peroxidase and polyphenoloxidase activity is 0.85 and $0.77 \mathrm{mg}$ of 1.4benzoquinone $\cdot \mathrm{g} 30 \mathrm{~min}^{-1}$, invertase activity is $7.8 \mathrm{mg}$ of glucose $10 \mathrm{~g} 24$ hour $^{-1}$, urease activity is $10.4 \mathrm{mg}$ of $\mathrm{NH}_{3} 10$ chlorine salts concentration of $40.1 \mathrm{mg} / \mathrm{dm}^{3}$ was used. The oil was applied to wet soil and stirred.

The ameliorants were applied according to the manufacturers requirements (Table 1) to uncontaminated 
and oil-contaminated soil. The uncontaminated nonameliorated soil was used as a control. Vessels incubation was performed at a temperature of $20-25^{\circ} \mathrm{C}$ while maintaining optimum soil moisture of $60 \%$. Observation time was 30,60 and 90 days. The experiments were conducted with 3 replications.

Model experiment No.2. Oil pollution-10\% of soil weight. Applied ameliorants: carbamide and potassium humate. Exposure time: 30, 60 and 90 days.

Experiment design:

1. Control $(\mathrm{C})-$ uncontaminated ordinary black soil

2. $\mathrm{C}+$ urea

3. $\mathrm{C}+$ potassium humate

4. Ordinary black soil contaminated by oil, $10 \%$ of soil weight $(\mathrm{O})$

5. $\mathrm{O}+$ urea

6. $\mathrm{O}+$ potassium humate

The model experiments were conducted with 3 replications. Biological parameters were determined with 318 analytical replications by standard methods (Kazeev et al., 2016).

Biological condition of soil was determined based on 12 indicators. Thus, carbon dioxide emission was determined using gas detector PGA-7 (in \%) and infrared sensor probe on $\mathrm{CO}_{2}$ gas detector TESTO-535 with an accuracy of $\pm 50 \mathrm{ppm}$ (in ppm $30 \mathrm{~min}^{-1}$ ); content of organic matter was determined by the Tyurin method modified by Nikitin, \%; catalase activity $\left(\mathrm{H}_{2} \mathrm{O}_{2}: \mathrm{H}_{2} \mathrm{O}_{2}\right.$ - oxidoreductase, $\mathrm{KF}$ 1.11.1.6.) was determined based on the rate of hydrogen peroxide decomposition when in contact with soil by the Galstyan method (1956), $\mathrm{mL}$ of $\mathrm{O}_{2} \mathrm{~g} \mathrm{~min}^{-1}$; peroxidase (donor: $\mathrm{H}_{2} \mathrm{O}_{2}$-oxidoreductase. $\mathrm{KF}$ 1.11.1.7.) and polyphenoloxidase (O-diphenol: oxygen-oxidoreductase. KF 1.10.3.1.) activity was determined based on the oxidation of hydroquinone in 1.4-benzoquinone by Karyagina, Mykhailova method (1986), mg of 1.4benzoquinone g $30 \mathrm{~min}^{-1}$; invertase activity ( $\beta$ fructofuranosidase, sucrase, KF 3.2.1.26) was determined by

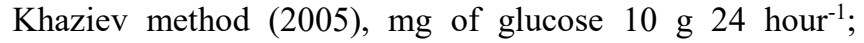
urease activity (carbamide - amidohydrolase, KF 3.5.1.5.) was determined by Galstyan method (1978), $\mathrm{mg}$ of $\mathrm{NH}_{3} \cdot 10$ g 24 hour $^{-1}$; phosphatase activity (orthophosphoric monoester phosphohydrolases. KF 3.1.3.1-2) was determined by Galstyan and Arutyunyan method (1966), mg of $\mathrm{P}_{2} \mathrm{O}_{5} 100 \mathrm{~g}^{\text {hour }}{ }^{-1}$; soil phytotoxicity was determined based on the change in the growth index of French Breakfast radish (Bab'eva, Zenova, 1989; Kazeev et al., 2016).
Integrated index of soil biological condition (IIBC) was calculated based on the most meaningful and sensitive biological parameters, i.e. catalase, invertase, phosphatase activity, length of radish root and shoot.

Residual content of oil was determined by infrared spectroscopy, $\mathrm{g} \quad \mathrm{kg}^{-1}$. Carbon tetrachloride (tetrachloromethane) was used as an agent for oil extraction from soil. The degree of oil extraction from soil by this method was $40 \%$.

Statistical data processing was carried out using Statistica 12.0. Dispersion and correlation analyses were used.

\section{Results and Discussion}

Impact of ameliorants on the biological condition of black soil was studied at $5 \%$ level of oil pollution. Figure 1 shows the residual content of oil in soil 30 days after application of ameliorants. This content was determined through oil extraction from soil by carbon tetrachloride. As shown in Figure 1, application of glauconite leads to rapid decrease in oil extraction percent (by 35\%) due to oil adsorption by glauconite. Application of three other ameliorants - Dop-Uni, potassium humate and urea leads to the decrease in oil content in soil as compared with control sample (13, 12 and $12 \%$, respectively). This is due to activation of native microbial flora caused by these compounds and intensification of oil breakdown.

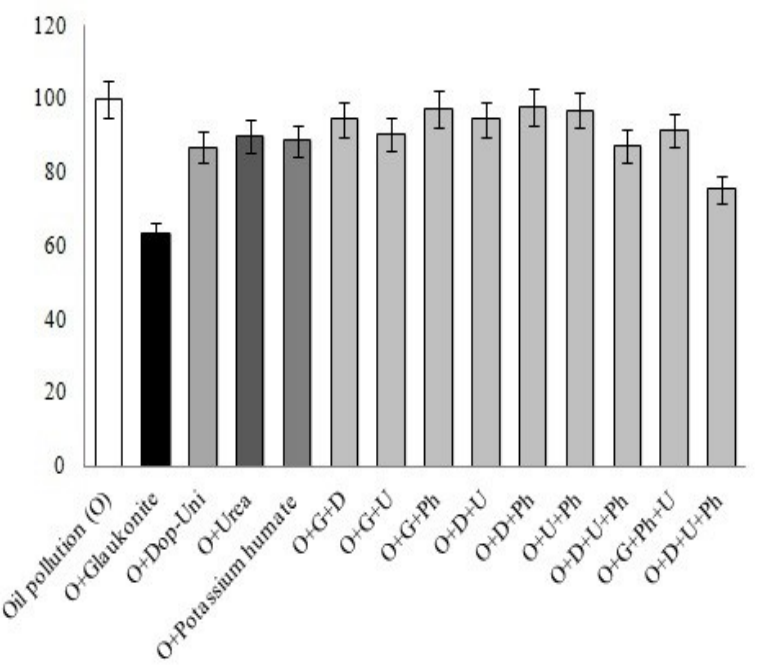

Figure 1: Content of oil in black soil 30 days after application of oil and ameliorants, $\%$ of initial oil content 
In other cases, the change in oil content was insignificant and was not substantially different from the probably caused by oxidizing reaction between hydroquinone, which is a good reducing agent, and urea.
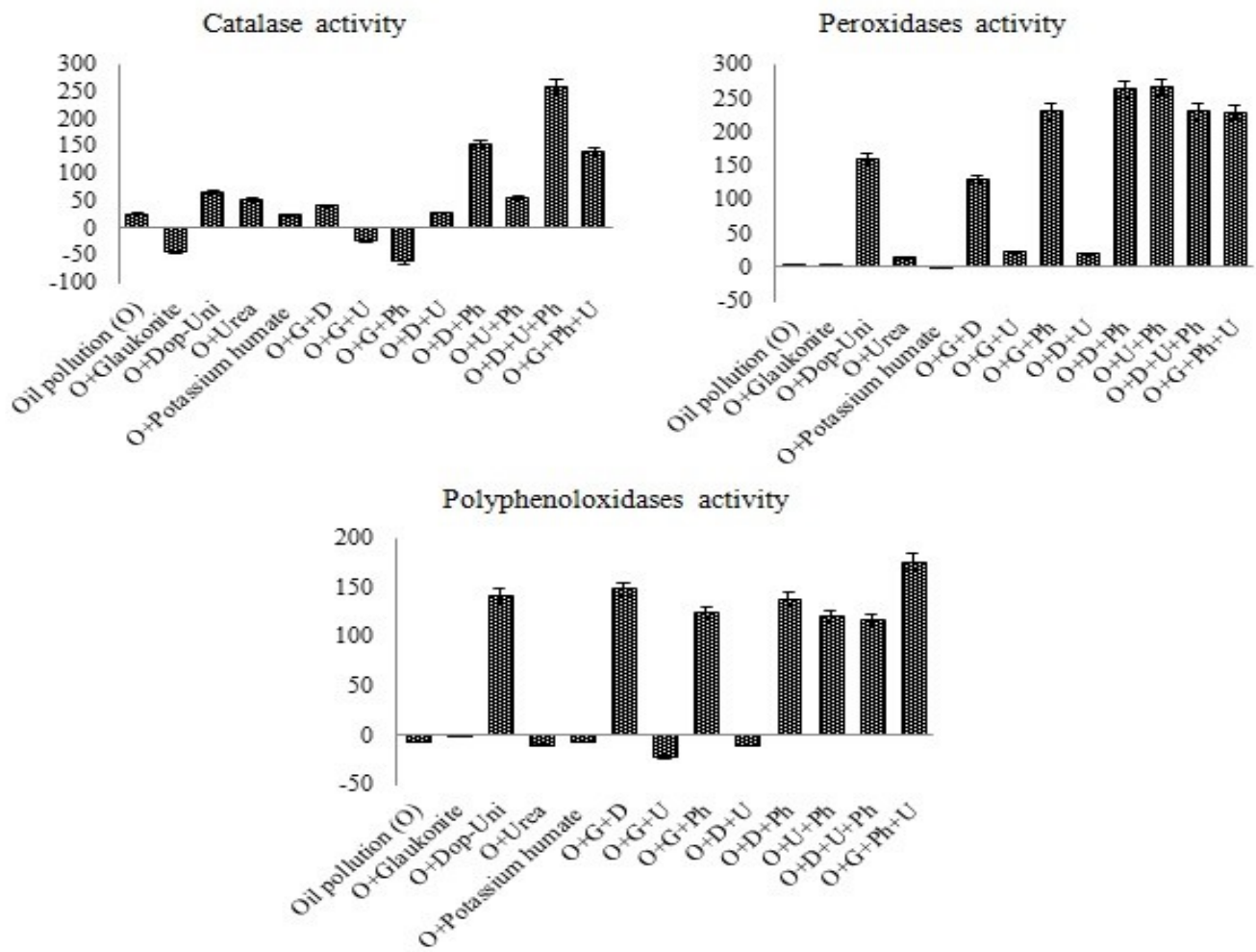

Figure 2: Change in oxidoreductase (catalase, peroxidases, polyphenoloxidases) activity 30 days after application of ameliorants, \% of oil-contaminated black soil

initial content. We believe that such slow decrease in oil content in soil is caused by short time of exposure and low concentration of oil. This is also confirmed by the results obtained by other authors (Suleymanov and Shorina, 2012).

\section{Change in oxidoreductase activity}

Oil pollution of $5 \%$ had a suppressing effect on catalase activity. i.e. enzyme activity was $25 \%$ lower than control value; peroxidases and polyphenoloxidases activity was not substantially influenced by oil pollution. Application of urea and potassium humate to oil-contaminated soil leads to the increase in catalase activity by 64 and $52 \%$ as compared with oil-contaminated soil (Figure 2). Complex application of these ameliorants leads to synergistic effect $-154 \%$ relative to oil.

Stimulation of peroxidases and polyphenoloxidases activity (by 159 and $140 \%$, respectively) after application of urea and combinations of other ameliorants with urea (229$264 \%$ for peroxidases, $110-175 \%$ for polyphenoloxidases) is

\section{Change in hydrolase activity}

Oil pollution had a suppressing effect on invertase, urease and phosphatase activity. Thus, enzymatic activity decreased by $30-80 \%$ (Figure 3). Separate application of ameliorants without oil had no significant effect or had a suppressing effect (urea and its combination with other ameliorants) on invertase activity.

In some cases (urea or combination of other ameliorants with urea), urease activity stimulation was higher by 130 $205 \%$ relative to oil-contaminated soil. Application of urea and its combinations with other ameliorants had a stimulating effect on urease activity, i.e. enzyme activity was higher than oil pollution level by $100-250 \%$. Application of Dop-Uni, urea and potassium humate has stimulating effect on phosphatase activity by 82,70 and $104 \%$ relative to oil pollution. Against the background of oil pollution, there was a decrease in invertase activity after application of all ameliorants, except for glauconite with potassium humate, which has reached control values. Stimulation of urease activity after combined application of 
several ameliorants, including glauconite and potassium humate, resulted from the method for enzyme activity determination. Since the method for the determination of urease activity in soil suggests the use of urea as a substrate, it would not be appropriate to assess urease activity in the experiments with urea applied as an ameliorant.
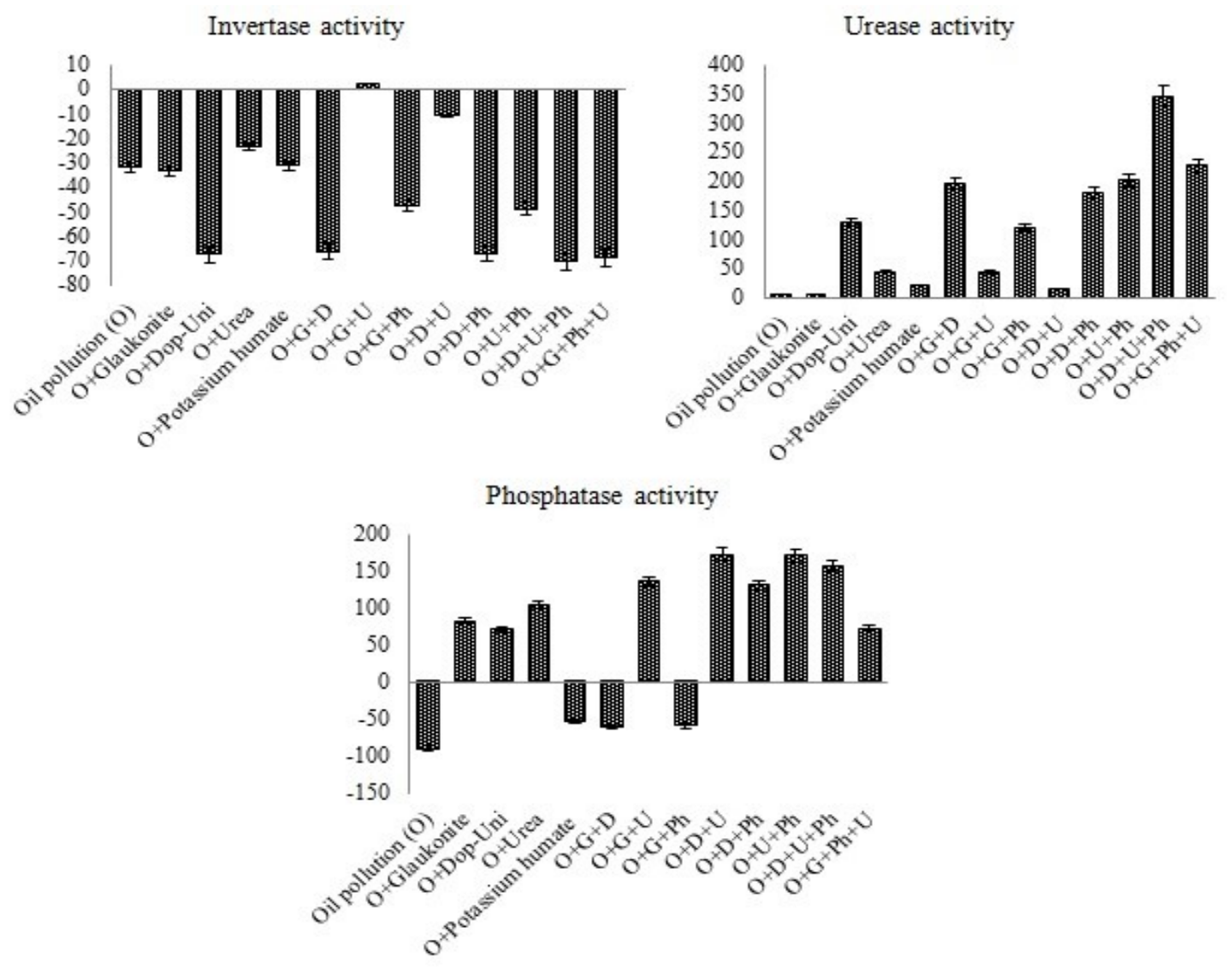

Figure 3: Change in hydrolase activity 30 days after application of ameliorants, \% of oil-contaminated black soil $3^{\text {rd }}$ day

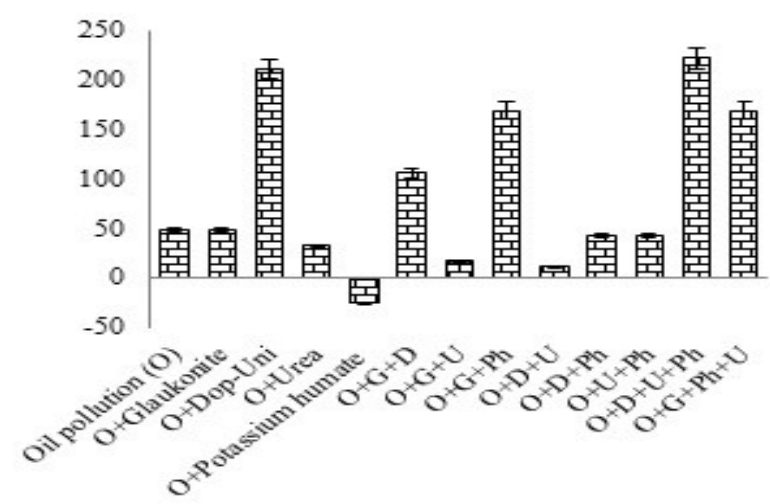

$20^{\text {th }}$ day

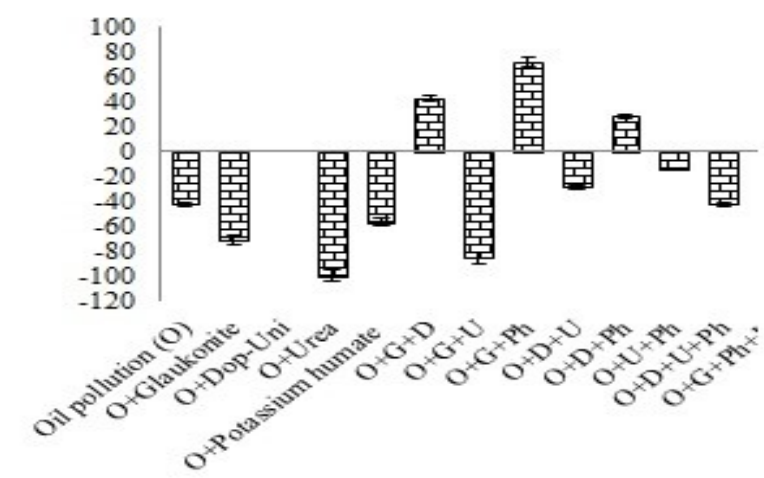

Figure 4: Change in $\mathrm{CO}_{2}$ emission in oil-contaminated ordinary black soil after application of ameliorants, \% of oil-contaminated black soil 
Emission of $\mathrm{CO}_{2}$ is a proxy indicator of microbiological activity. Thus, in case of $5 \%$ oil pollution, after 3 and 20 days, $\mathrm{CO}_{2}$ emission exceeded the control value by 50 and $100 \%$, respectively (Figure 4).

Shoot length

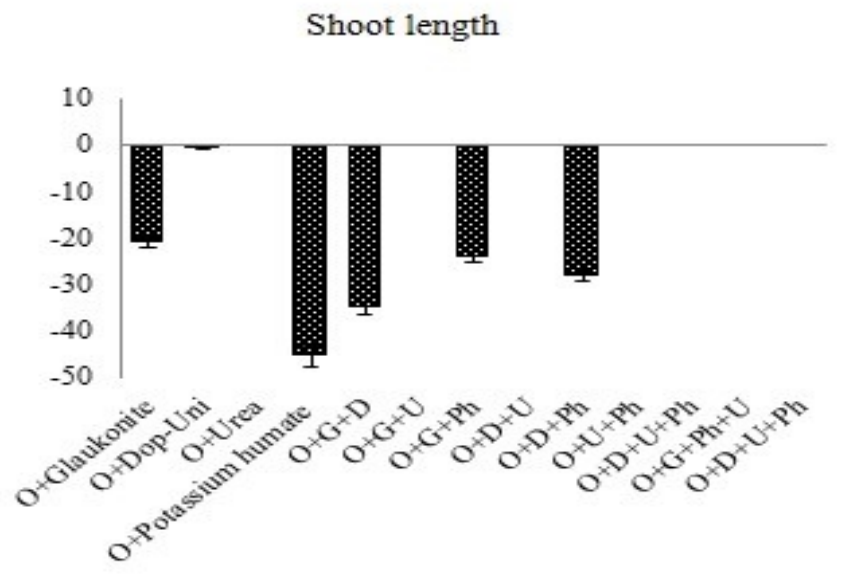

Oil pollution had insignificant stimulating effect on germination capacity and root length of radish (Figure 5). Application of urea separately and combined with other ameliorants has completely suppressed the development of

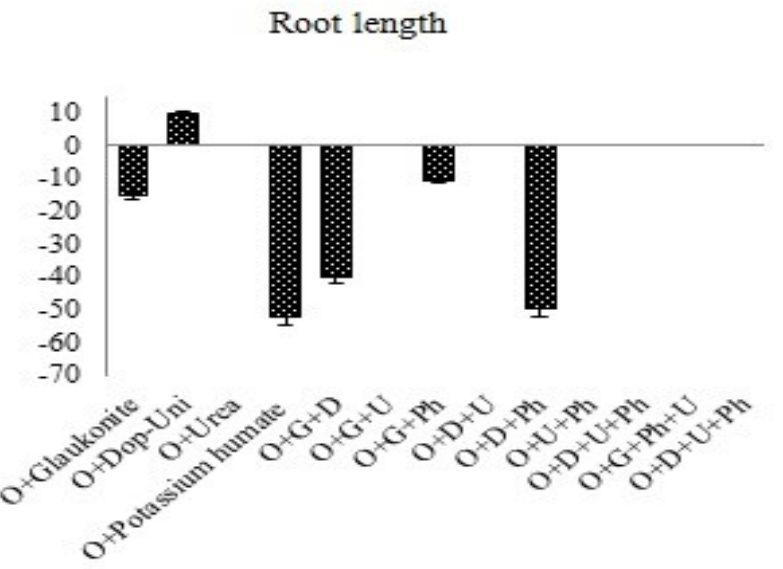

\section{Figure 5: Change in phytotoxicity of oil-contaminated ordinary black soil after application of ameliorants, $\%$ of oil-contaminated black soil}

Application of urea and its combinations with other ameliorants both without oil pollution and at oil pollution had a significant stimulating effect on the $3^{\text {rd }}$ day and $20^{\text {th }}$ day. Emission of $\mathrm{CO}_{2}$ exceeded the control value by $100-$ $300 \%$ relative to oil pollution. Apparently, this is due to the activation of soil biota that facilitates oil degrading.

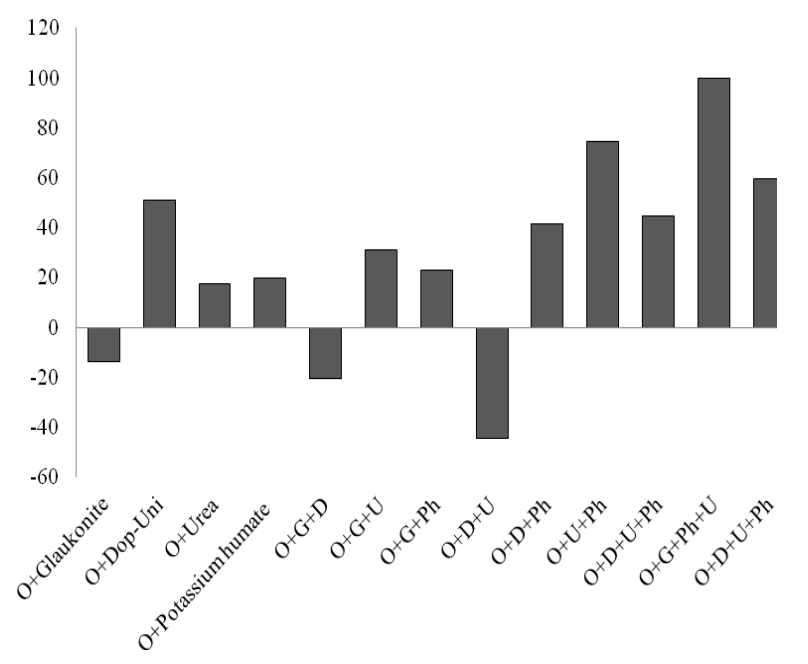

Figure 6: Change in IIBC of black soil at $5 \%$ oil pollution after 30 days, \% of oil-contaminated black soil radish. Separate application of glauconite, Dop-Uni, potassium humate and combinations with potassium humate had a stimulating effect on the length of roots and shoots by $60-82 \%$ relative to control value. Such stimulation is caused by positive effect on soil biota that facilitated oil degrading.

In cases with urea, application of ameliorants to oilcontaminated black soil leads to high soil toxicity. In case of Dop-Uni application, soil toxicity is minimal, i.e., in line with control value or $10 \%$ higher.

At $5 \%$ oil pollution, integration index biological activity (IIBA) of black soil decreased by $25 \%$ relative to control value. Application of Dop-Uni and potassium humate and urea to soil not contaminated by oil resulted in IIBC increase (Figure 6). This is indicative of their bio stimulating action. Application of urea leads to the reduction of black soil biological activity. The same pattern with regard to urea impact on the biological activity of oilcontaminated soils was observed earlier in the experiments conducted by S. I. Kolesnikov et al. (2011). Application of Dop-Uni to oil-contaminated soil leads to IIBC stimulation by $50 \%$. By comparison, application of potassium humate and urea resulted in the exceedance (in case with oil) by 17.5 and $20.0 \%$, respectively. The similar tendency to the stimulation was defined at combined application of potassium humate with other ameliorants, as well as DopUni with other ameliorants. 
In case of combined application of urea and potassium humate, there is a synergistic effect indicating the reasonability of their combined application. When applying urea with Dop-Uni, there is an antagonistic effect.

Impact of ameliorants on the biological condition of black soil at $10 \%$ level of oil pollution. In the second part of the research, attention is focused on the study of impact of urea and potassium humate. These compounds were chosen based on the previous data on positive impact of urea and potassium humate on the biological properties of oil-contaminated black soil. Oil concentration in soil is $10 \%$. Exposure time: 30, 60 and 90 days.

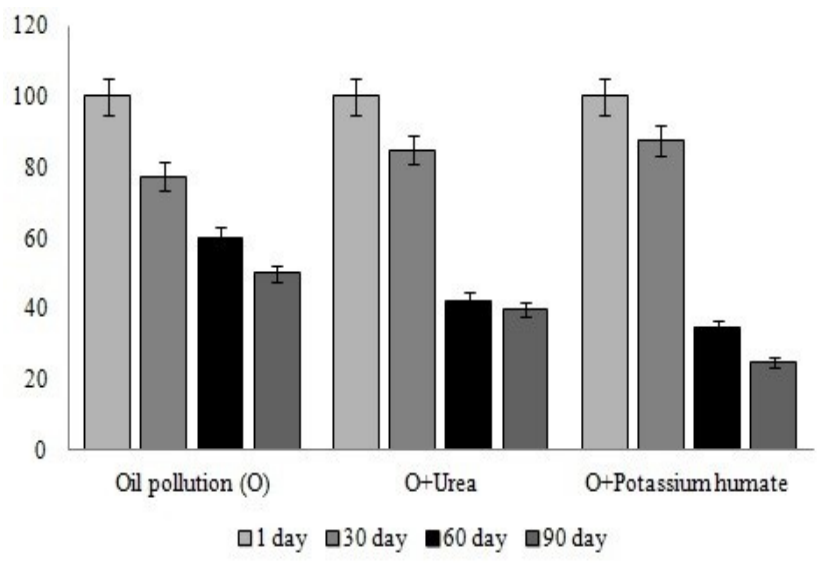

Figure 7: Change in oil content in soil 30, 60 and 90 days after application of oil and ameliorants, \% of initial content

Residual content of oil in soil (Figure 7) decreased by 22, 40 and $50 \%$ after 30, 60 and 90 days, respectively.

Application of urea and especially potassium humate increased oil breakdown level on the $60^{\text {th }}$ and $90^{\text {th }}$ days by 57 and $60 \%$ (after application of urea) and by 65 and $75 \%$ (after application of potassium humate).

Black soil pollution by oil had suppressing effect on catalase, invertase and phosphatase activity. The decrease was $18-80 \%$ relative to control value (Figure 8 ). The most sensitive enzyme was phosphatase, suppression of which was $40-80 \%$.

Application of urea reduced catalase activity by 25 $60 \%$ and stimulated phosphatase activity by $75-150 \%$. Invertase activity significantly varied: suppressing effects were observed after 30 and 90 days and stimulating effects (by $25 \%$ higher than control value) were recorded after 60 days.

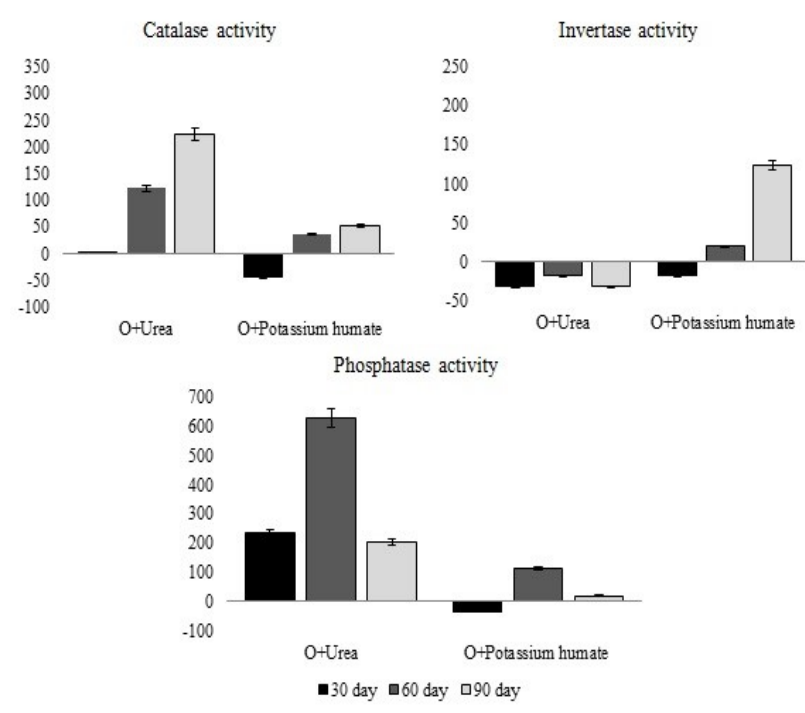

Figure 8: Change in enzymatic activity in black soil 30, 60 and 90 days after application of potassium humate and urea, $\%$ of oil-contaminated soil

Application of potassium humate had no significant effect on catalase and phosphatase activity.

Application of urea to oil-contaminated soil increased catalase activity by $123-224 \%$ and phosphatase activity by $203-629 \%$, while suppressing invertase activity by $18-32 \%$ relative to control value. Application of potassium humate to oil-contaminated soil did not show regenerating effect on catalase and phosphatase activity, however after 90 days, it stimulated invertase activity by $117 \%$ as compared with oil pollution.

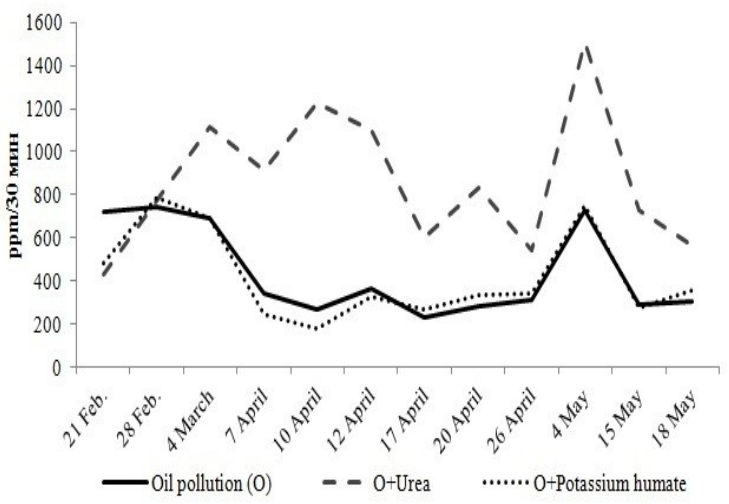

Figure 9: Change in $\mathrm{CO}_{2}$ emission 30, 60 and 90 days after application of potassium humate and urea, ppm.30 min $^{-1}$ 
After application of oil, $\mathrm{CO}_{2}$ emission increased by $42 \%$ of initial value (Figure 9). After application of urea and potassium humate, there was an increase in $\mathrm{CO}_{2}$ emission with a small decline within 90 days.

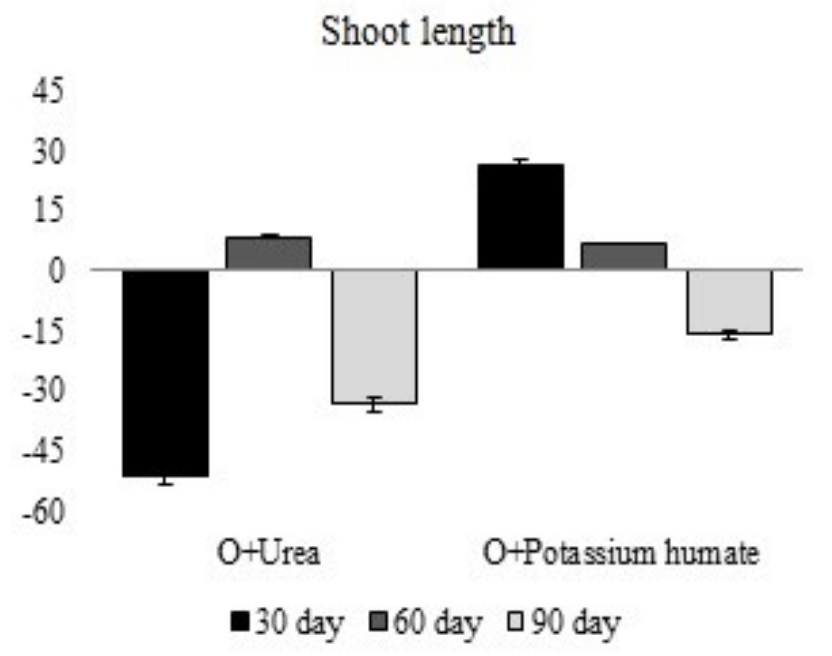

phytotoxic indicator (length of radish roots) was stimulated on the $30^{\text {th }}$ and $90^{\text {th }}$ days relative to oil pollution by 31 and $69 \%$, respectively.

IIBA of black soil was estimated at oil pollution level

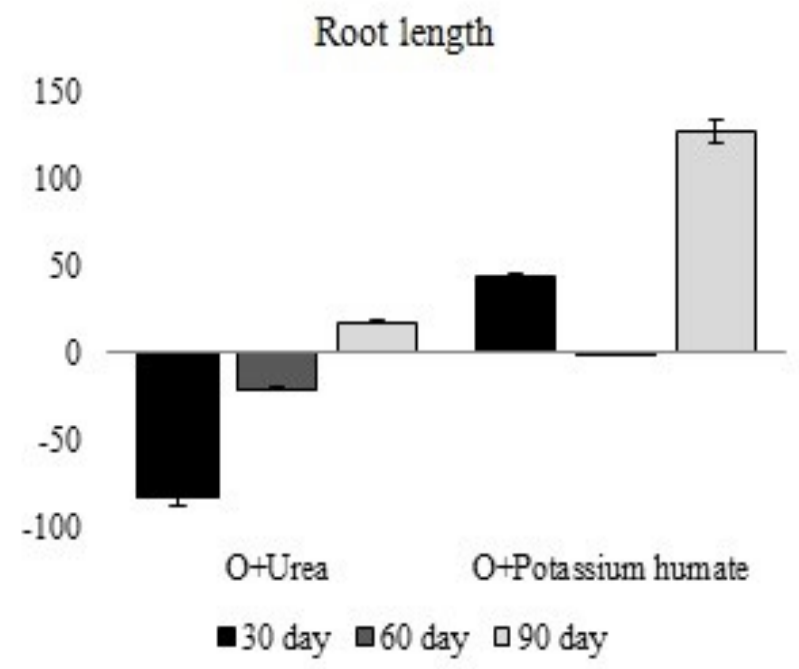

Figure 10: Change in phytotoxic parameters of radish in uncontaminated and oil-contaminated black soil 30, 60 and 90 days after application of potassium humate, \% of oil-contaminated black soil

Decrease in $\mathrm{CO}_{2}$ emission is probably caused by oil breakdown in soil as shown in Figure 8. The largest increase in $\mathrm{CO}_{2}$ emission (by $67 \%$ ) as compared with oilcontaminated black soil was observed after application of urea to oil-contaminated black soil.

Oil pollution had a suppressing effect on germination capacity, length of roots and shoots by $18-50 \%$ after 30 and 60 days (Figure 10). Application of urea against the background of oil pollution after 30 and 60 days had greater toxic effect than oil pollution itself. However, after 90 days, the parameters under study increased. In particular, germination capacity and shoot length recovered to control level.

Application of urea had a negative impact on roots and shoots length after 30 and 60 days by $60-80 \%$ and on germination capacity after 60 and 90 days by $78-80 \%$. Application of potassium humate after 30 and 90 days stimulated all the parameters under study by $20-65 \%$ relative to control value. Application of potassium humate against the background of oil pollution had a rehabilitating effect, i.e. germination capacity of radish increased on the $30^{\text {th }}$ and $90^{\text {th }}$ days by 31 and $69 \%$, respectively. Stimulation of shoots length developed on the $30^{\text {th }}$ and $60^{\text {th }}$ days by 26 and $7 \%$, respectively. The most meaningful of $10 \%$ of soil weight 30,60 and 90 days after application of urea and potassium humate (Figure 11). It is confirmed that oil pollution leads to decrease in IIBA by 30,45 and $22 \%$ of control value after 30,60 and 90 days, respectively.

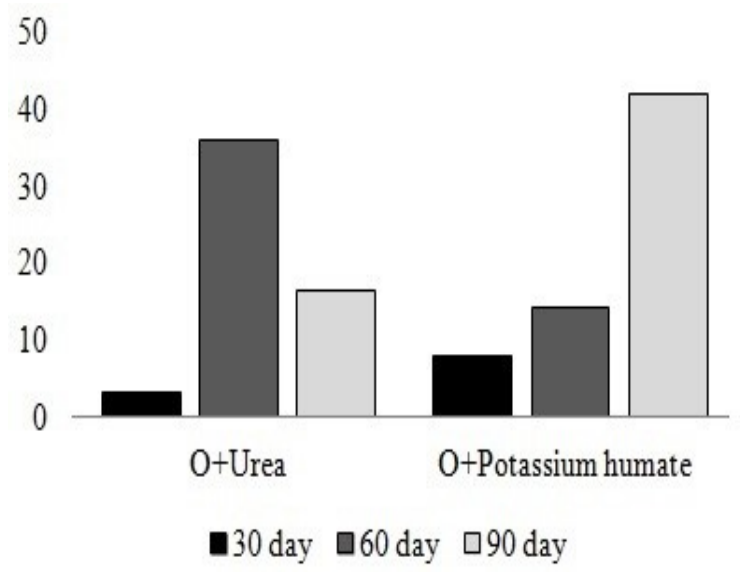

Figure 11: Change in IIBA of black soil at $10 \%$ oil pollution after 30, 60 and 90 days, \% of oilcontaminated black soil 
Application of urea to oil-contaminated black soil leads to increase in IIBA by 36 and $16 \%$ on the $60^{\text {th }}$ and $90^{\text {th }}$ days, respectively; application of potassium humate leads to increase of IIBC by 14 and $42 \%$ on the $60^{\text {th }}$ and $90^{\text {th }}$ days, respectively.

Sensitivity of biological parameters to the application of ameliorants in case of black soil pollution by oil was estimated based on the degree of biological parameter decline from control value.

According to the sensitivity to ameliorants in oilcontaminated black soils, biological parameters form the following sequence: invertase activity $>$ catalase activity $>$ phosphatase activity $\geq$ urease activity $>$ root length $\geq$ shoot length $\geq$ peroxidases activity $\geq$ polyphenoloxidases activity $\geq$ bacterial count.

Information value of biological parameters in the application of ameliorants to oil-contaminated black soil was assessed based on the correlation of biological parameter with ameliorant dose.

According to information value, the used biological parameters of soil condition form the following sequence: invertase activity $>$ catalase activity $>$ peroxidases activity $>$ polyphenoloxidases activity $>$ root length $>$ shoot length $>$ phosphatase activity $\geq$ urease activity $>$ bacterial count.

\section{Conclusion}

Impact of ameliorants on the biological activity of oilcontaminated black soil depends on the nature of ameliorant. According to the stimulating effect on the biological activity of oil-contaminated black soil, the studied ameliorants rank in the following order: potassium humate (humic agent) > glauconite (mineral adsorbent) > Dop-Uni (bacterial preparation) $>$ urea (source of nitrogen). Potassium humate, as a biological stimulant of native oil degrading microbiota, has the most beneficial impact on the biological properties of black soil at any level of oil pollution. Biological properties of black soil recovered up to the level of uncontaminated soil 90 days after oil pollution and application of potassium humate.

According to the stimulation of oil breakdown, the studied ameliorants form the following sequence: potassium humate (humic agent) > Dop-Uni (bacterial preparation) $>$ urea (source of nitrogen). The above rank does not include glauconite, since its mode of action is based not on the stimulation of oil breakdown, but on its fixation.
Impact of ameliorants was dependent on the exposure time. Application of ameliorants on the $30^{\text {th }}$ day had impact on the rate of oil destruction; on the $60^{\text {th }}$ and $90^{\text {th }}$ days, application of urea accelerated natural breakdown of oil 1.5 times, application of potassium humate -2 times.

In case of combined application of ameliorants, both synergistic and antagonistic effects are observed. Application of urea with potassium humate leads to synergistic effect; application of urea with Dop-Uni leads to antagonistic effect.

According to the sensitivity to ameliorants in oilcontaminated black soils, biological parameters form the following sequence: invertase activity $>$ catalase activity $>$ phosphatase activity $\geq$ urease activity $>$ root length $\geq$ shoot length $\geq$ peroxidases activity $\geq$ polyphenoloxidases activity $\geq$ bacterial count.

According to the information value, the biological parameters used in the study form the following sequence: invertase activity $>$ catalase activity $>$ peroxidases activity $>$ polyphenoloxidases activity $>$ root length $>$ shoot length $>$ phosphatase activity $\geq$ urease activity $>$ bacterial count.

Integrated index of biological condition of oilcontaminated black soil after application of ameliorants was maximum after application of Dop-Uni and potassium humate. Maximum IIBA was observed on the 60th day after urea application and on the 90th day after potassium humate application.

\section{Acknowledgments}

The study has been carried out with the support of the Ministry of Education and Science of the Russian Federation (5.5735.2017/8.9) and the President of the Russian Federation (NSH-3464.2018.11).

\section{References}

Latif, S.A., S. Sharif, S.M. Hossain, M.A. Islam, I.M. Mehedi and M.S. Sultana. 2019 Heavy metal contamination of surface soils in southern part of Bangladesh. Soil and Environment 38(1): 112-118.

Ahmad, N., M.K. Bismillah, S. Farooq, M. Shahzad, M. Farooq and H. Mubashar. 2015. Potassium nutrition improves the maize productivity under water deficit conditions. Soil and Environment 34(1): 15-26.

Ashraf, M., M. Sher, S.M. Imtiaz, M.S. Rizwan, and M.M. Iqbal. 2017. Ameliorative effects of potassium nutrition on yield and fiber quality characteristics of cotton (Gossypium hirsutum L.) under $\mathrm{NaCl}$ stress. Soil and Environment 36(1): 51-58 DOI: 10.25252/SE/17/31054 
Bab'eva, M.A., N.K. Zenova 1989. Biologiya pochv. M.: Izd-vo MGU, Moscow, $336 \mathrm{p}$.

Batool, R., S. Ayub and I. Akbar. 2017 Isolation of biosurfactant producing bacteria from petroleum contaminated sites and their characterization. Soil and Environment 36(1): 35-44.

Dindar, E., F.O.T. Şağban and H.S. Başkaya. 2015. Variations of soil enzyme activities in petroleumhydrocarbon contaminated soil. International Biodeterioration \& Biodegradation 105: 268-275.

Efremova, S.Yu., T.A. Sharkov and M.S. Avakov. 2016. Razrabotka ekologicheski bezopasnosti vysokoeffektivnogo sposoba rekul'tivacii pochv, zagryaznennyh nefteproduktami. XXI vek: itogi proshlogo i problemy nastoyashchego plyus 4 (32): 48-54.

Erkenova, M.I., I.I. Tolpeshta, S.Ya. Trofimov, R.S. Aptikaev and A.S. Lazarev. 2016. Izmenenie soderzhaniya nefteproduktov v zagryaznennoj neft'yu torfyanoj pochve verhovogo bolota $\mathrm{v}$ usloviyah polevogo eksperimenta $\mathrm{s}$ ispol'zovaniem izvesti i udobrenij. Pochvovedenie 11: 1392-1401.

Filatov, D.A., A.A. Ivanov, L.I. Svarovskaya and N.V. Yudina. 2011. Vliyanie svetokorrektiruyushchej plenki i guminovyh kislot na biohimicheskoe okislenie nefti v pochve. Agrohimiya 10: 76-82.

Gabbasova, I.M., R.F. Abdrahmanov, I.K. Habirov and F.H. Haziev. 1997. Izmenenie svojstv pochv i sostava gruntovyh vod pri zagryaznenii neft'yu i neftepromyslovymi stochnymi vodami $\mathrm{v}$ Bashkirii. Pochvovedenie 11: 1362-1372.

Ismailov, N.M. F.H. Khaziev 1988. Mikrobiologiya i fermentativnaya aktivnost' neftezagryaznennyh pochv. Vosstanovlenie neftezagryaznennyh pochvennyh ekosistem M.: Nauka. 42-56.

Kanis'kin, M.A., V.A. Terekhova and A.S. Yakovlev. 2007. Kontrol' gumatnoj detoksikacii orthodox fosfogipsa metodami biotestirovaniya. Ekologiya $i$ promyshlennosti Rossii 48-51.

Kazeev, K.S., S.I. Kolesnikov, Yu.V. Akimenko and E.V. Dadenko. 2016. Metody biodiagnostiki nazemnyh ekosistem. Rostov-na-Donu: Izdatel'stvo YuFU, 356.

Khaziev, F.H., E.I. Tishkina, N.A. Kireeva and G.G. Kuziahmetov. 1988. Vliyanie neftyanogo zagryazneniya na nekotorye komponenty ekosistemy. Agrohimiya 2: 56-61.

Kireeva, N.A. 1998. Biohimicheskaya indikaciya pochv, zagryaznennyh neft'yu i nefteproduktami. Zashchita okruzhayushchej sredy $v$ neftegazovom komplekse. 3:11-14.

Kireeva, N.A., A.S. Grigoriadi and E.F. Hajbullina. 2009. Associacii

uglevodorodokislyayushchih mikroorganizmov dlya bioremediacii neftezagryaznennyh pochv. Vestnik Bashkirskogo universiteta 14. 2: 391-394.

Kireeva, N.A., E.I. Novoselova, and A.S. Grigoriadi. 2009. Vliyanie zagryazneniya pochv neft'yu na fiziologicheskie pokazateli rastenij i rizosfernuyu mikrobiotu. Agrohimiya 7: 71-80.

Kolesnikov, S.I., D.K. Aznaur'yan, K.S. Kazeev and T.V. Denisova. 2011. Izuchenie vozmozhnosti ispol'zovaniya mocheviny $\mathrm{i}$ fosfogipsa $\mathrm{v}$ kachestve meliorantov neftezagryaznennyh pochv $\mathrm{v}$ model'nom opyte. Agrohimiya 9: 77-81.

Kolesnikov, S.I., K.S. Kazeev, M.L. Tatosyan and V.F. Val'kov. 2006. Vliyanie zagryazneniya neft'yu i nefteproduktami na biologicheskoe sostoyanie chernozema obyknovennogo. Pochvovedenie 5: 616620.

Kolesnikov, S.I., K.S. Kazeev, V.F. Val'kov, D.K. Aznaur'yan and M.G. Zharkova. 2007. Biodiagnostika ekologicheskogo sostoyaniya pochv, zagryaznennyh neft'yu i nefteproduktami. Rostov n/D: Izd-vo ZAO Rostizdat 192.

Kolesnikov, S.I., R.K. Tatlok, Z.R. Tlekhas, K.S. Kazeev, T.V. Denisova and E.V. Dadenko. 2013. Biodiagnostika ustojchivosti predgornyh i gornyh pochv Zapadnogo Kavkaza k zagryazneniyu neft'yu i nefteproduktami. Doklady Rossijskoj akademii sel'skohozyajstvennyh nauk 1: 30-34.

Minnikova, T.V., S.I. Kolesnikov, T.V. Denisova and Yu.V. Akimenko. 2018b. Biodiagnosis of the state of oil-polluted chernozem during remediation with urea and potassium humate. $18^{\text {th }}$ International Multidisciplinary Scientific Geo Conference SGEM Conference Proceedings 18: 33-40.

Minnikova, T.V., S.I. Kolesnikov, T.V. Denisova and Yu.V. Akimenko. 2018c. Integral'naya ocenka biologicheskogo sostoyaniya chernozema obyknovennogo pri remediacii neftezagryazneniya. Problemy agrohimii i ekologii No. 3. S.56-60.

Minnikova, T.V., T.V. Denisova, S.I. Kolesnikov and Yu.V. Akimenko. 2018a. Assessment of agroecological indicators of oil-contaminated Chernozem in Rostov Oblast after remediation with urea and potassium humate. Russian Agricultural Sciences 44. 2: 177-180.

Minnikova, T.V., T.V. Denisova, S.S. Mandzhieva, S.I. Kolesnikov, T.M. Minkina, V.A. Chaplygin, M.V. Burachevskaya, S.N. Sushkova and T.V. Bauer. 2017. Assessing the effect of heavy metals from the Novocherkassk power station emissions on the biological activity of soils in the adjacent areas. Journal of Geochemical Exploration 174: 70-78. 
Pikovskyi, Yu.I. 2003. Problemy diagnostiki i normirovaniya zagryazneniya pochv neft'yu i nefteproduktami. Pochvovedenie 9: 1132-1140.

Polyak, Y.M., L.G. Bakina, M.V. Chugunova, M.V. Mayachkina, A.O. Gerasimova and V.M. Bureb. 2018. Effect of remediation strategies on biological activity of oil-contaminated soil - A field study. International Biodeterioration \& Biodegradation 126: 57-68.

Suleymanov, R.R., T.S. Shorina 2012. Vliyanie neftyanogo zagryazneniya na dinamiku biohimicheskih processov chernozema obyknovennogo (Orenburgskaya oblast'). Izvestiya Samarskogo Nauchnogo Centra RAN. 14. 1: 240-243.
Suleymanov, R., I. Saifullin, M. Komissarov, I. Gabbasova, A. Suleymanov and T. Garipov 2019. Effect of phosphogypsum and turkey litter on the erodibility of agrochernozems of the southern CisUral (Russia) under artificial heavy rainfall. Soil and Environment 38(1): 81-89.

Trofimov, S., Ya. Ammosova and D.S. Orlov. 2000. Vliyanie nefti na pochvennyj pokrov i problema sozdaniya normativnoj bazy po vliyaniyu neftezagryazneniya na pochvy. Vestnik $M G U$. Series 17(2): $30-34$. 